\title{
Characterization of in situ dry matter and protein degradation of green and ensiled oats forages at three stages of growth
}

\author{
AES Borba 1, JMC Ramalho Ribeiro 2 \\ 'Departamento de Ciências Agrarias, Universidade dos Açores, 9700 Angra do Heroismo; \\ 2Departamento de Nutriçao, Estaçao Zootécnia Nacional, 2000 Vale de Santarém, Portugal
}

Oat (Avena sativa L.) is one of the forages produced in the Azores for use as green forage or as silage. Oats were cut at three stages of growth, namely : fifth leaf stage $(\mathrm{F})$, bolt stage (B) and milky kernal stage (M) and was analysed both green $(G)$ and ensiled $(E)$.

The in situ method uses nylon bags made of nylon cloth (Hydro-Bios- NY55 HC) measuring $17 \times 9 \mathrm{~cm}$ and with a pore size of $55 \mu \mathrm{m}$. For each bag about $5 \mathrm{~g}$ of the sample were weighed. The bags were incubated by $0,1,3$, $6,12,24,48$ and 72 hours in the rumen of three adult males sheep. The zero-hour bags were only washed in running water for 15 minutes. When taken out of the rumen, the bags were washed under running water, until the rinsing water was colourless, and dried at $65^{\circ} \mathrm{C}$. In the incubation residues we have determined the weight of dry matter (DM) and the crude protein (CP) content.

The DM and CP degradability $(p)$ at each of a series of incubation times ( $t$ ) is exponential and can be described, following Orskov et al (1980, Trop Anim Prod, 5, 195-213), by the equation : $p=a+b\left(1-e^{-c}\right)$ where $a, b$ and $c$ are constants particular to each forage, $a$ is the measure of the rapidly soluble dry matter or protein fraction, $b$ the fraction subjected to degradation and $c$ the constant rate of disappearance of fraction $b$. The constant a was determined by the $D M$ and $C P$ degradability in the zero-hour bags. The potential DM and CP degradability $(a+b)$ and the constant $c$ were estimated by the method of Ørskov and McDonald (1979, J Agric Sci, Camb, 92, 499-503).

The DM degradability decreases significantly $(P \leq 0.05)$ with the advance of the plant development and is also significantly higher $(P \leq 0.05)$ in green forages than in ensiled forages, this difference is practically null in the later stage of forage development.

The CP degradability is significantly higher $(P \leq 0.05)$ in ensiled forages than in green forages, this is a consequence of the proteolysis in the ensilage process, and decreases significantly $(P \leq 0.05)$ with the advance of the stage of growth, but from a different way in green and ensiled forages. Vik-Mo (1989a, Acta Agric Scand, 39, 34-52) reported also that the effective $C P$ degradability is higher in silages than in green crops, and Vik-Mo (1989b, Acta Agric Scand, 39, 53-64) found a decrease of the nitrogen degradability in silages, following the advance of the plant development.

We can assume that the in situ DM degradability of the green and ensiled oat forages decreases with the advance of the plant stage of growth and is higher in green forages than in ensiled forages. The in situ $\mathrm{CP}$ degradability is higher in ensiled oats than in green oats, and also decreases with the advance of the oat stage of growth.

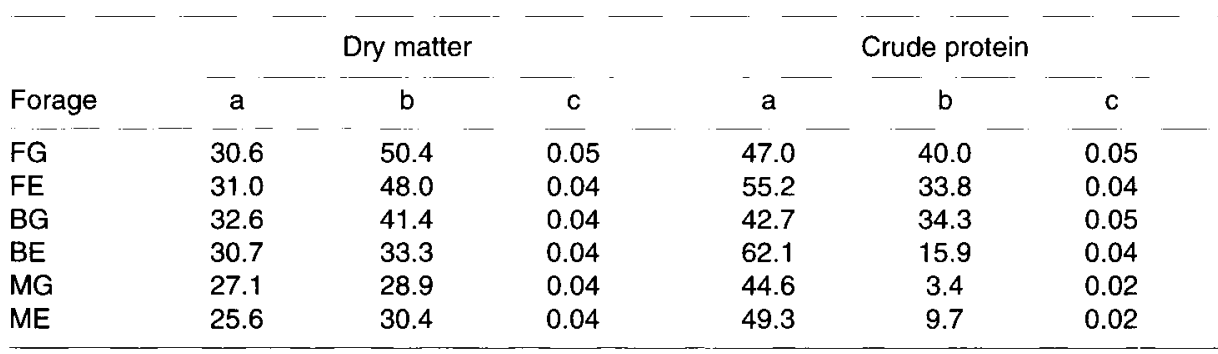

